\title{
PENGARUH EFEKTIVITAS MODAL KERJA TERHADAP PEROLEHAN SISA HASIL USAHAPADA KOPERASI CADDIE BGG JATINANGOR
}

\author{
Mukhlizar $^{1}$, Yosika Adriani Siti Fauziah ${ }^{2}$ \\ ${ }^{1}$ Jurusan Teknik Industri, F. TEKNIK Universitas Teuku Umar \\ ${ }^{2}$ Jurusan Manajemen, F. Ekonomi Institut Manajemen Koperasi Indonesia \\ E-mail: ${ }^{1}$ mukhlizar@utu.ac.id, ${ }^{2}$ pesonayosika@gmail.com.
}

\begin{abstract}
Abstrak
Penelitian ini bertujuan untuk mengetahui pengaruh modal kerja terhadap perolehan laba bersih, seberapa besar pengaruh dan faktor-faktor yang menjadi penyebabnya. Untuk mengetahui seberapa besar pengaruh korelasi regresi terhadap perhitungan X (Modal Kerja) Y (Laba Bersih). Dan menghasilkan $r=0,254$ berarti bahwa efektivitas penggunaan modal kerja terhadap laba bersih pada koperasi ini memiliki hubungan yang lemah. Maksudnya, penggunaan modal kerja secara efektif hanya memberi sedikit efek pada perolehan laba bersih. Berdasarkan hasil tersebut dapat dilihat juga determinan koefisien $k d=r^{2} \times 100 \%=6,45 \%$ yang berarti bahwa laba bersih mempengaruhi efektifitas penggunaan modal kerja sebesar 6,45\% dan sisanya 93,55\% Dipengaruhi oleh faktor lain diluar Studi. Dan untuk mengetahui faktor-faktor yang mempengaruhinya, yaitu dengan rasio aktivitas analisis deskriptif.
\end{abstract}

\section{Kata Kunci:Efektivitas, Modal Kerja, Sisa Hasil Usaha.}

\section{PENDAHULUAN}

Koperasi merupakan organisasi otonom yang berada pada lingkungan sosial ekonomi, yang memungkinkan setiap individu dan setiap kelompok orang merumuskan tujuan-tujuannya secara otonom dan mewujudkan tujuan-tujuan itu melalui aktifitas-aktifitas ekonomi yang dilaksanakan secara bersama-sama, koperasi juga dapat digunakan sebagai alat penunjang kegiatan ekonomi individu yang merasa kebutuhannya belum terpenuhi dengan usaha yang dilakukannya selama ini [1].

Caddie merupakan salah satu jenis pekerjaan yang tidak tetap sifatnya, memandu dan menjadi asisten bagi para pemain golf. Mereka memiliki gaji yang tidak tetap, atau disebut pekerja lepas. Artinya mereka memiliki upah pada saat bekerja saja, dan jam pekerjaan tidak tetap berbeda dengan buruh- buruh yang bekerja di pabrik. Maka dari penghasilan tidak tetap tersebut, caddie membutuhkan badan usaha yang dapat memperingan pemenuhan kebutuhan ekonomi sehari-harinya.

Koperasi Caddie BGG Jatinangor terletak di Bandung Giri Gahana Golf (BGG) Jatinangor Desa Cikeruh Kecamatan Jatinangor merupakan salah satu koperasi yang didirikan untuk memenuhi kebutuhan anggota yaitu caddie di BGG ini. Bisnis utamanya adalah simpan pinjam dan pengadaan barang.

Setoran awal yang dibayarkan pada saat menjadi anggota koperasi yaitu berupa simpanan pokok senilai Rp.1000,- dan simpanan wajib yang berasal dari potongan caddiefee setiap kali bekerja. Semakin sering caddie bekerja semakin sering ia akan menyetorkan simpanannya pada koperasi. Hal ini juga dapat memperkuat struktur modal sendiri koperasi.

Modal kerja digunakan untuk kegiatan usaha dimana hasilnya diharapkan dapat menghasilkan laba, dari laba yang diperoleh dapat diketahui apakah penggunaan dana telah efektif 
atau tidak efektif. Berdasarkan survei pengambilan data di lapangan menunjukan bahwa modal kerja pada tahun 2008 sebesar Rp. 2,210,258,849 yang artinya modal kerja di tahun tersebut meningkat, namun tidak diikuti dengan peningkatan SHU yaitu sebesar Rp. 107,500,067. Sementara pada tahun 2009 modal kerja mengalami penurunan yaitu sebesar Rp. 2,269,979,679 namun hal ini diikuti dengan penurunan SHU yaitu sebesar Rp.104,278,589 Pada tahun berikutnya yaitu pada tahun 2010 terjadi peningkatan modal kerja kembali namun tidak terlalu signifikan yaitu sebesar Rp. 2,137,887,545 dan hal ini diikuti dengan peningkatan SHU yaitu sebesar Rp. 78,161,967. Pada tahun 2011 terjadi peningkatan modal kerja kembali yaitu sebesar Rp. 2,590,103,729 dan hal ini diikuti dengan peningkatan SHU yaitu sebesar Rp. 79,052,499. Pada tahun 2012 dan 2013 terjadi peningkatan modal kerja kembali yaitu sebesar Rp. 3,180,722,148, hingga Rp. 3,574,201,159 dan hal ini diikuti dengan peningkatan SHU yaitu sebesar Rp. 84,017,960 hingga Rp. 108,511,224 berdasarkan data yang telah di uraikan bahwa peningkatan modal kerja tidak selalu diikuti dengan peningkatan SHU.

\section{METODOLOGI PENELITIAN}

\subsection{Pengertian Koperasi}

Koperasi merupakan badan usaha yang beranggotakan orang seorang atau badan hukum koperasi dengan melandaskan kegiatannya berdasarkan prinsip-prinsip koperasi sekaligus sebagai gerakan ekonomi rakyat yang berdasar atas azas kekeluargaan [2].

\subsection{Pengertian Modal}

Modal merupakan kolektivitas dari barang-barang modal yang terdapat dalam neraca sebelah debet, sedangkan yang dimaksud barang-barang modal adalah semua barang yang ada dalam rumah tangga perusahaan dalam fungsi produktifnya untuk membentuk pendapatan. Yang dimaksud kekayaan adalah daya beli yang terdapat dalam barang-barang modal. Dengan demikian maka kekayaan terdapat dalam neraca sebelah kredit [3].

\subsection{Efektivitas Modal kerja}

Efektivitas modal kerja merupakan pemanfaatan modal kerja dalam aktivitas operasional perusahaan secara optimal sehingga mampu meningkatkan kemakmuran bagi perusahaan itu sendiri. Penggunaan modal akan dinyatakan optimal jika jumlah modal kerja yang digunakan perusahaan mampu menghasilkan keuntungan yang besar pula bagi manajemen. Efektivitas modal kerja ini menunjukkan prestasi manajemen dalam mengelola sumber perusahaan secara optimal. Semakin efektif kegunaan modal kerja, maka akan semakin baik kinerja perusahaan. Untuk mengukur efektivitas modal kerja yang harus dilakukan adalah menghitung perputaran elemen-elemen dari modal kerja itu sendiri [4].

Untuk mengukur efektivitas modal kerja yang harus dilakukan adalah menghitung perputaran elemen-elemen dari modal kerja itu sendiri. Elemen dalam modal kerja itu terdiri dari kas, piutang dan persediaan.

1. Perputaran Kas

Perputaran kas (cashturnover) adalah perbandingan antara sale dengan jumlah kas rata-rata. Tingkat perputaran kas merupakan ukuran efisiensi penggunaan kas yang dilakukan oleh perusahaan. Karena tingkat perputaran kas menggambarkan kecepatan arus kas kembalinya kas yang telah ditanamkan di dalam modal kerja. Kas diperlukan perusahaan baik untuk membiayai operasi perusahaan sehari-hari maupun untuk mengadakan investasi baru dalam aktiva tetap. Dalam mengukur tingkat perputaran kas, sumber masuknya kas yang telah tertanam dalam modal kerja adalah berasal dari aktivitas operasional perusahaan. Oleh karena itu, sumber kas dalam penelitian ini adalah berasal dari aktivitas penjualan. Makin tinggi tingkat perputaran kas berarti makin cepat kembalinya kas masuk pada perusahaan. Dengan demikian kas akan dapat 
dipergunakan kembali untuk membiayai kegiatan operasional sehingga tidak mengganggu keuangan perusahaan.

2. Perputaran Piutang

Perputaran piutang merupakan periode terikatnya modal dalam piutang yang bergantung pada syarat pembayarannya. Makin lunak atau semakin lama syarat pembayarannya berarti semakin lama modal terikat pada piutang yang berarti bahwa tingkat perputarannya selama periode tertentu adalah semakin rendah.

3. Perputaran Persediaan

Inventory atau persediaan barang sebagai elemen utama dari modal kerja merupakan alat yang selalu dalam keadaan berputar, dimana secara terus-menerus mengalami perubahan. Masalah investasi atau alokasi modal dalam persediaan mempunyai efek yang langsung terhadap keuntungan perusahaan. Kesalahan dalam penerapan besarnya investasi dalam persediaan akan menekan keuntungan perusahaan.Adanya investasi dalam persediaan yang terlalu besar dibandingkan dengan kebutuhan akan memperbesar berbagai bunga, memperbesar biaya penyimpanan dan pemeliharaan di gudang, memperbesar kemungkinan kerugian karena kerusakan, turunnya kualitas, keusangan, sehingga akan memperkecil keuntungan perusahaan.Demikian pula sebaliknya, adanya investasi yang terlalu kecil dalam persediaan mempunyai efek yang menekan keuntungan juga. Apabila kekurangan material, perusahaan tidak dapat bekerja dengan luas produksi yang optimal. Oleh karena itu perusahaan tidak bekerja full-capacity, berarti bahwa "capital assets" dan "direct-labor" tidak dapat didayagunakan dengan sepenuhnya, sehingga hal ini akan mempertinggi biaya produksi, yang pada akhirnya akan menekan keuntungan yang diperoleh.Dalam perusahaan perdagangan pada dasarnya hanya ada satu golongan inventory yang mempunyai sifat perputaran yang sama yaitu yang disebut "merchandise inventory" atau persediaan barang dagangan. Inventory ini merupakan persediaan barang yang selalu dalam perputaran, yang selalu dibeli dan dijual.

\subsection{Sisa Hasil Usaha}

Sisa Hasil Usaha (SHU) adalah gabungan dari hasil partisipasi neto dan laba atau rugi kotor dengan non anggota, ditambah atau dikurangi dengan pendapatan dan beban lain serta beban perkoperasian dan pajak penghasilan badan koperasi [5].

Salah satu indikator keberhasilan koperasi dalam memperbaiki keadaan sisa hasil usaha dalam melaksanakan aktivitas usahanya diantaranya yaitu:

1. Pendapatan

Pendapatan adalah peningkatan jumlah aktiva atau penurunan kewajiban suatu badan usaha yang timbul dari penyerahan barang atau jasa atau aktivitas usaha lainnya di dalam suatu periode [6].

2. Harga Pokok Penjualan

Harga pokok penjualan terjadi karena adanya transaksi pembelian persediaan dan penjualan barang. Harga pokok penjualan hanya ada pada perusahaan dagang yang menjual barang dagangan, sedangkan pada perusahaan jasa dan perusahaan manufaktur tidak memperhitungkan harga pokok penjualan [7].

3. Biaya

Biaya adalah pengorbanan sumber ekonomi, yang diukur dalam satuan uang, yang telah terjadi atau kemungkinan akan terjadi untuk tujuan tertentu [8].

\subsection{Metode yang Digunakan}

Dalam penelitian ini menggunakan metode studi kasus, yaitu melakukan penelitian dengan mencari atau merumuskan masalah berdasarkan data yang ada. Berdasarkan analisis deskriptif dari pengamatan langsung terhadap objek yang diteliti, sehingga diharapkan dapat memecahkan permasalahan yang ada di koperasi [9]. 


\subsection{Macam Data}

Data tentang keadaan umum Koperasi Caddie BGG Jatinangor meliputi:

1. Laporan keuangan (laporan neraca, laporan rugi/laba Koperasi Caddie BGG Jatinangor.

2. Keadaan organisasi dan Manajemen Koperasi Caddie BGG Jatinangor.

3. Keadaan wilayah kerja Koperasi Caddie BGG Jatinangor

4. Data dan informasi lain yang mendukung pada penelitian yang akan dilaksanakan.

\subsection{Cara Pengumpulan Data} sebagai berikut:

Untuk memperoleh data yang diperlukan dalam penelitian ini, dapat dilakukan dengan cara

1. Wawancara, yaitu data yang dikumpulkan dengan wawancara langsung dengan mengajukan pertanyaan terhadap pihak yang terkait, baik kepada responden maupun informan.

2. Observasi, yaitu pengumpulan data dengan melakukan pengamatan langsung terhadap objek yang diteliti.

3. Studi Pustaka, yaitu teknik pengumpulan data yang dilakukan dengan cara membaca literaturliteratur dan buku-buku yang berhubungan dengan masalah yang diteliti.

\subsection{Analisis Data}

Analisis data harus dapat menjawab semua identifikasi masalah kemudian mendeskripsikannya dari apa yang ada dan telah dilaksanakan. Untuk menjawab identifikasi masalah yang pertama yaitu untuk mengetahui sejauh mana efektivitas penggunaan modal kerja dan faktorfaktor yang mempengaruhi di Koperasi Caddie BGG Jatinangor, akan dijawab dengan menggunakan rumus [10]:

Perputaran Modal Kerja $\frac{\text { Pendapatan Bersih }}{\text { Rata-rata Modal Kerja }} 1$ kali

Perputaran
Kas

Kas

Perputaran Piutang Barang $\frac{\text { Penjualan Kredit }}{\text { Piutang Rata-rata }} 1$ kali

Perputaran Persediaan $\frac{\text { Harga Pokok Persediaan }}{\text { Rata-rata Persediaan }} 1$ kali

Untuk mengetahui keeratan hubungan antara penggunaan modal dengan perolehan selisih hasil usaha, maka akan diuji dengan menggunakan rumus analisis regresi korelasi sebagai berikut.

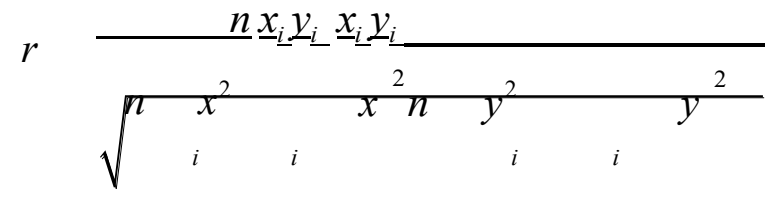

Keterangan:

$$
\begin{aligned}
& r: \text { koefisien korelasi } \\
& n: \text { jumlah periode atau tahun } \\
& \text { : efektivitas penggunaan modal kerja }
\end{aligned}
$$


$\checkmark$

perolehan

sisa hasil

usaha 


\section{HASIL DAN PEMBAHASAN}

\subsection{Perkembangan Perputaran Modal Kerja}

Berdasarkan hasil perhitungan perputaran modal kerja menunjukan bahwa hasilnya berfluktuasi, pada tahun 2009 perputaran menurun dikarenakan pendapatan koperasi yang menurun, akan tetapi ratarata modal kerja naik pada tahun ini hal ini menunjukkan perputaran modal kerja di tahun ini tidak efektif. Pada tahun 2010 terjadi kenaikan perputaran modal kerja ini dikarenakan pendapatan yang meningkat dan rata-rata modal kerja yang menurun sehingga periode terikatnya dana lebih cepat dari tahun sebelumnya, perputaran modal kerja dinilai efektif di tahun ini.

Pada tahun 2011 perputaran modal kerja kembali meningkat dan periode terikatnya modal kerja lebih baik dari tahun sebelumnya, hal ini dikarenakan oleh pendapatan yang meningkat. Pada tahun 2012 dan 2013 terjadi penurunan perputaran modal kerja sehingga menyebabkan periode terikatnya dana semakin lama dari tahun-tahun sebelumnya hal ini dikarenakan pendapatan yang meningkat namun diikuti dengan peningkatan rata-rata modal kerja yang cukup tinggi, perputaran modal kerja dinilai tidak efektif di dua tahun terakhir ini, untuk lebih jelasnya dapat dilihat pada gambar 3.1 . berikut.

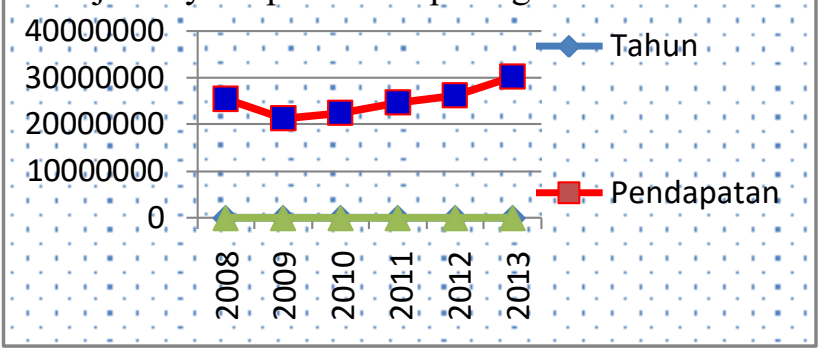

\section{Gambar 3.1. Perkembangan Perputaran Modal Kerja Koperasi Caddie BGG Jatinangor}

Jika dilihat dari rata-rata modal kerja setiap tahunnya Koperasi Caddie BGG Jatinangor selalu mengalami peningkatan kecuali pada tahun 2009. Dari kondisi tersebut diharapkan terjadinya kenaikan pendapatan, namun dengan bertambahnya modal kerja justru pendapatan cenderung menurun. Oleh karena itu penggunaan modal kerja bisa dikatakan cenderung semakin tidak ef ektif. Kondisi ini dikarenakan kurangnya partisipasi anggota yang memiliki sebagai pelanggan yang seharusnya lebih banyak bertransaksi di koperasi. Untuk mengetahui lebih jauh faktor-faktor yang menyebabkan efektivitas modal kerja Koperasi Caddie BGG, maka dilakukan analis terhadap masing-masing unsur-unsur modal kerja.

\subsection{Perputaran Kas}

Berdasarkan hasil perhitungan perputaran kas menunjukan bahwa pada tahun 2009 perputaran kas mengalami penurunan ini dikarenakan terjadinya penurunan pendapatan. Namun pada tahun 2010 dan 2011 perputaran kas mengalami kenaikan karena adanya kenaikan pendapatan di dua tahun ini, partisipasi anggota pada koperasi cukup baik dan perputaran kas dinilai efektif. Pada tahun 2012 perputaran mengalami penurunan karena rata-rata kas di tahun ini naik dan tidak diikuti dengan kenaikan pendapatan yang signifikan, perputaran kas di tahun ini dinilai tidak efektif. Namun pada tahun 2013 perputaran modal kerja kembali mengalami kenaikan hal ini dikarenakan peningkatan rata-rata kas di tahun ini diikuti dengan peningkatan pendapatan yang persentasenya jauh lebih tinggi, untuk lebih jelasnya dapat dilihat pada gambar grafik 3.2. berikut. 


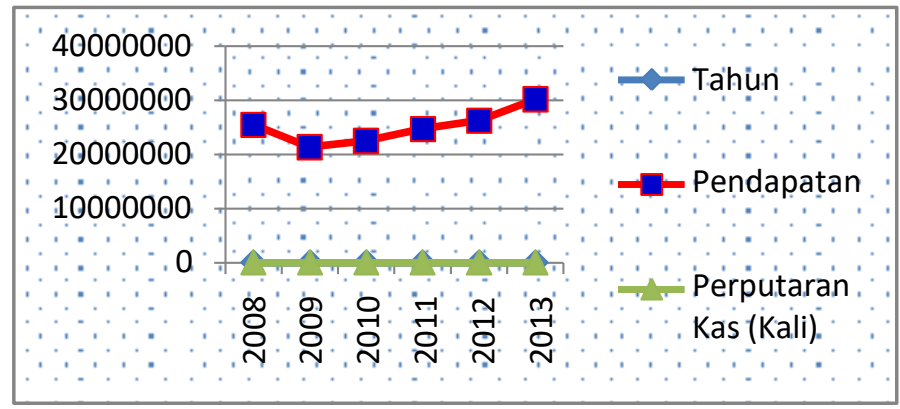

Gambar 3.2. Perkembangan Perputaran Kas Koperasi Caddie BGG Jatinangor periode 20082013

Jika dilihat dari grafik diatas menunjukan bahwa meningkatnya perputaran modal kerja pada tahun terakhir yang disebabkan oleh meningkatnya pendapatan koperasi, menunjukkan peningkatan partisipasi anggota dalam bertransaksi di koperasi. Meskipun jika dilihat dari periode terikatnya waktu koperasi ini masih kurang baik karena periode berputarnya kas lebih dari satu tahun.

\subsection{Perputaran Piutang}

Berdasarkan hasil perhitungan perputaran piutang dapat dilihat bahwa perputaran piutang pada tahun 2009 mengalami penurunan hal ini dikarenakan volume penjualan kredit yang menurun tetapi ratarata piutang naik, perputaran piutang di tahun ini dinilai tidak efektif. Namun pada tahun 2010 dan 2011 terjadi kenaikan perputaran piutang dikarenakan penjualan kredit pada dua tahun ini meningkat, dan hal ini menyebabkan perputaran piutang dinilai efektif. Namun pada tahun 2012 dan 2013 perputaran piutang turun dan dinilai tidak efektif, untuk lebih jelasnya dapat dilihat pada gambar 3.3 grafik perputaran piutang berikut.

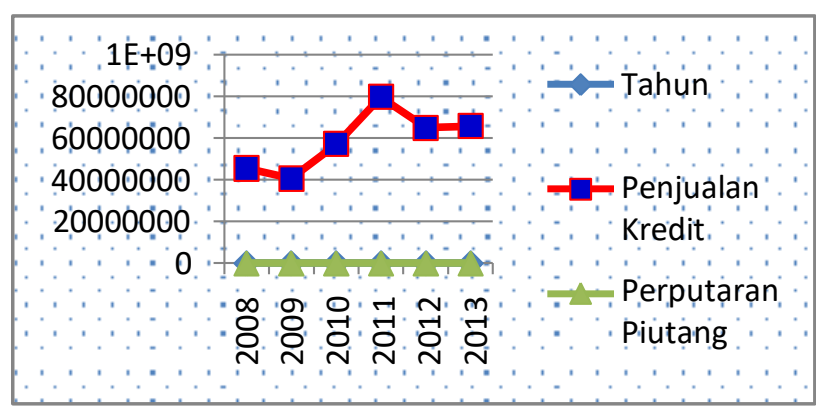

\section{Gambar 3.3. Perkembangan Perputaran Piutang Unit Usaha Pengadaan Barang Koperasi Caddie BGG Jatinangor Periode 2008-2013}

Jika dilihat dari grafik diatas menunjukan bahwa penjualan kredit yang menurun pada tahuntahun terakhir namun rata-rata piutang dari tahun ke tahun semakin naik menyebabkan perputaran piutang yang tidak efektif hal ini mengidentifikasikan kurangnya partisipasi anggota dalam pembayaran hutangnya pada koperasi. Kebijakan penagihan kredit juga harus diperbaiki agar perputaran piutang tidak selalu menurun pada periode berikutnya.

\subsection{Unit Simpan Pinjam}

Berdasarkan hasil perhitungan unit simpan pinjam terlihat bahwa perputaran piutang pada tahun 2009 dan 2010 mengalami penurunan hal ini dikarenakan pendapatan jasa pinjaman di tahun ini menurun, perputaran piutang tahun ini dinilai tidak efektif. Pada tahun 2011 dan 2012 perputaran piutang pada unit 
ini mengalami kenaikan, perputaran piutang dinilai efektif. Namun pada tahun 2013 kembali mengalami penurunan dan dinilai tidak efektif, untuk lebih jelașnya dapat dilihat pada gambar 3.4. berikut.

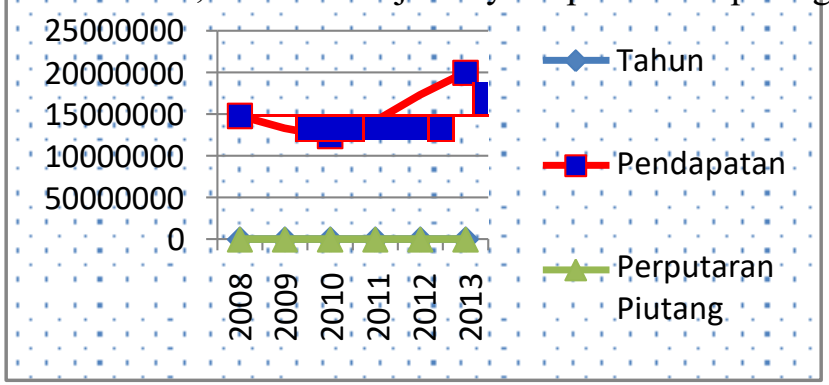

\section{Gambar 3.4. Perkembangan Perputaran Piutang Unit Simpan Pinjam Koperasi Caddie BGG Jatinangor Periode 2008-2013}

Jika dilihat dari grafik diatas menunjukan bahwa perputaran piutang pada tahun terakhir yang tidak efektif disebabkan karena partisipasi anggota yang kurang aktif dalam pengembalian cicilan.

\subsection{Perputaran Persediaan}

Perputaran persediaan merupakan kemampuan persediaan barang untuk berputar hingga kembali lagi menjadi persediaan ala satu periode tertentu. Dalam kegiatan usahanya koperasi menjual barang dagangannya secara tunai maupun secara kredit, dengan demikian koperasi perlu menyediakan barangbarang tersebut dalam jumlah yang cukup. Hal ini untuk mengantisipasi kekurangan pada saat-saat tertentu. Persediaan barang dagang ini selalu dibeli dan dijual, karena itu persediaan mengalami perputaran dalam satu periode.

Semakin cepat perputaran persediaan menunjukkan bahwa transaksi yang terjadi di koperasi dan semakin lama perputaran persediaan menunjukkan transaksi yang terjadi di koperasi sedikit. Berdasarkan hasil perhitungan perputaran persediaan untuk lebih jelasnya dapat dilihat pada gambar 3.5. grafik perkembangan perputaran persediaan berikut.

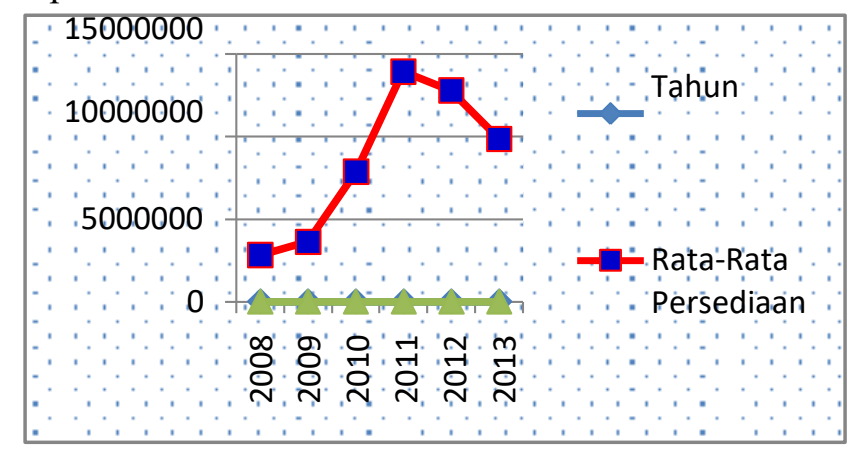

\section{Gambar 3.5. Perkembangan Perputaran Persediaan Koperasi Caddie BGG Jatinangor Periode 2008-2013}

Jika dilihat dari gambar grafik diatas menunjukan bahwa perputaran persediaan mengalami penurunan setiap tahunnya dan dinilai tidak efektif, terkecuali pada tahun 2013 perputaran persediaan mengalami kenaikan hal ini dikarenakan rata-rata persediaan yang menurun dibanding tahun sebelumnya. Pada tahun terakhir ini penggunaan persediaan dinilai efektif. 


\subsection{Faktor-faktor yang Mempengaruhi Turunnya Tingkat Perputaran Modal KerjaKoperasi Caddie BGG Jatinangor}

Faktor yang mempengaruhi turunnya tingkat perputaran modal kerja koperasi Caddie BGG Jatinangor diantaranya meliputi:

1. Besarnya Jumlah Kas yang Menganggur (Idle Money)

Kas merupakan salah satu unsur terpenting dalam modal kerja. Keahlian manajerial koperasi dalam pengelolaan kas akan berpengaruh pada tinggi rendahnya perputaran modal kerja pada koperasi. Koperasi Caddie BGG Jatinangor memiliki jumlah kas yang cukup besar, yang sebenarnya masih dapat digunakan untuk pengembangan aktivitas usaha yang dapat menghasilkan keuntungan bagi koperasi ini. Selalu meningkatnya jumlah kas setiap periode tahun menunjukkan adanya dana yang tidak produktif dan mempengaruhi turunnya perputaran modal kerja yaitu pada unsur perputaran kas menjadi tidak efektif.

2. Lamanya Periode Pengumpulan Piutang

Perputaran piutang adalah kemampuan piutang untuk berputar hingga kembali lagi menjadi kas dalam satu periode. Semakin lama syarat pembayaran berarti semakin lama modal terikat dalam piutang yang berarti bahwa tingkat perputarannya selama periode tertentu semakin rendah. Hal ini juga terjadi pada Koperasi Caddie BGG Jatinangor, kurangnya penetapan syarat yang jelas dalam pembayaran piutang menjadikan piutang yang ada di koperasi semakin besar jumlahnya namun tidak diikuti dengan peningkatan pendapatan. Partisipasi anggota dalam pembayaran hutangnya merupakan unsur penting yang mempengaruhi tinggi rendahnya perputaran piutang yang juga akan berpengaruh pada perputaran modal kerja.

\subsection{Pengaruh Efektivitas Penggunaan Modal Kerja Terhadap Perolehan Sisa Hasil Usaha}

Untuk mengetahui sejauh mana pengaruh tingkat efektivitas penggunaan modal kerja yaitu tingkat perputaran modal kerja sebagai dengan SHU sebagai variabel dapat dianalisis menggunakan analisis regresi korelasi, untuk lebih jelasnya dapat dilihat pada gambar 3.6. grafik perhitungan analisis regresi korelasi efektivitas penggunaan modal kerja terhadap sisa hasil usaha berikut.

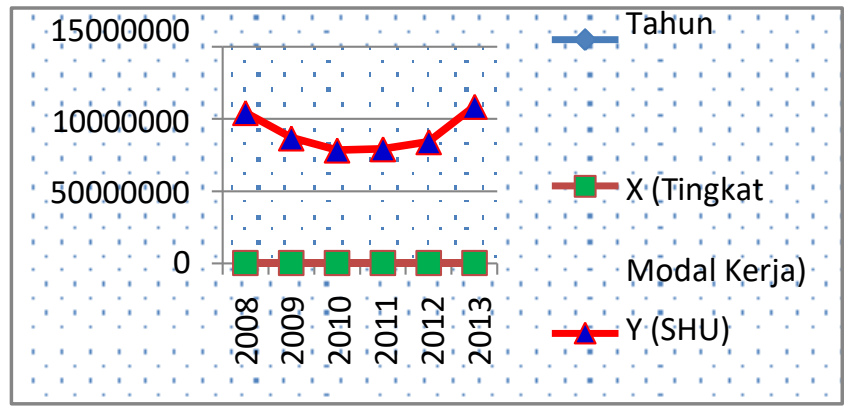

Gambar 3.6. Perhitungan Analisis Regresi Korelasi Efektivitas Penggunaan Modal Kerja Terhadap Sisa Hasil Usaha

Berdasarkan gambar grafik diatas menunjukan bahwa koefisien korelasi sebesar $r$ 0,254

artinya bahwa efektivitas penggunaan modal kerja terhadap sisa hasil usaha memiliki hubungan yang lemah. Artinya semakin efektif penggunaan modal kerja berpengaruh kecil terhadap perolehan SHU. Keeratan hubungan ini didasarkan kepada aturan Guilford. Koefisien determinasi bernilai 6,45\% berarti tingkat perolehan sisa hasil usaha (variabel) dipengaruhi oleh tingkat perputaran modal kerja (variabel) sebesar $6,45 \%$ dan sisanya $93,55 \%$ dipengaruhi faktor lain.Dari analisis terhadap kegiatan Usaha Koperasi Caddie BGG Jatinangor menunjukkan bahwa dengan jumlah modal kerja yang tinggi dan cenderung naik tidak menjamin tingkat perolehan sisa hasil usaha yang tinggi pula begitu pun sebaliknya. Tingkat perolehan sisa hasil usaha tidak hanya dipengaruhi oleh tingkat perputaran modal kerja saja tetapi

93,55\% dipengaruhi oleh faktor lain seperti efisiensi pengeluaran biaya untuk menghasilkan pendapatan, 
karena dengan persentase biaya yang kecil terhadap pendapatan, dapat mempengaruhi perolehan sisa hasil usaha. Perolehan SHU juga dipengaruhi oleh kebijakan harga dan pelayanan.

\section{KESIMPULAN}

Setelah dilakukan pembahasan kembali mengenai pengaruh efektivitas penggunaan modal kerja terhadap perolehan sisa hasil usaha, maka diperoleh beberapa kesimpulan:

1. Perputaran modal kerja selama enam tahun terakhir berfluktuasi, perputaran modal kerja yang menurun disebabkan karena peningkatan rata-rata modal kerja setiap tahunnya tidak diikuti dengan peningkatan pendapatan di setiap unit usaha yang dimiliki oleh koperasi maka dalam beberapa tahun efektivitas modal kerja pada koperasi dinilai tidak efektif. Ini merupakan pengaruh dari kurangnya partisipasi anggota dalam aktivitas usaha koperasi sehingga pendapatan yang dimiliki koperasi kurang optimal, atau kurang maksimalnya peran manajerial koperasi dalam pemanfaatan modal kerja yang semakin bertambah setiap tahunnya.Untuk melihat lebih jauh faktor-faktor yang mempengaruhi efektivitas penggunaan modal kerja maka bisa dilihat perkembangan perputaran unsur-unsurnya, antara lain perputaran kas, perputaran piutang dan perputaran persediaan.

1) Perputaran kas, berdasarkan hasil pembahasan perputaran kas pada Koperasi Caddie BGG Jatinangor perputaran kas berfluktuasi meskipun pada akhir tahun perputaran kas kembali meningkat. Namun jika dilihat dari periode terikatnya dana perputaran kas di koperasi ini dinilai kurang efektif karena periode terikatnya dana terlalu lama yaitu lebih dari satu tahun. Hal ini disebabkan karena rata-rata kas yang tinggi tidak diikuti dengan jumlah pendapatan yang tinggi. Hal ini menandakan koperasi belum mampu mengelola kasnya dengan baik sehingga perputaran kas menjadi salah satu faktor tidak efektifnya modal kerja.

2) Perputaran piutang, berdasarkan hasil pembahasan pengelolaan piutang pada tahun-tahun terakhir cenderung tidak efektif dan piutang merupakan unsur terbesar aktiva lancar. Ketidakefektifan pengelolaan piutang yang ditunjukkan oleh perputaran piutang yang rendah. Hal ini terjadi karena partisipasi anggota yaitu kesadaran dalam mengembalikan pinjaman rendah. Rendahnya perputaran piutang menjadi salah satu faktor kurang efektifnya perputaran modal kerja.

3) Perputaran persediaan, pada tahun terakhir meningkat, hal ini dikarenakan turunnya rata-rata persediaan pada tahun ini artinya partisipasi anggota pada tahun terakhir dalam pembelian barang di koperasi meningkat. Namun pada tahun-tahun sebelumnya persediaan selalu menurun, ini menjadi salah satu faktor turunnya efektivitas modal kerja.

2. Berdasarkan hasil analisis dapat disimpulkan $r=0,254$ artinya bahwa efektivitas penggunaan modal kerja terhadap sisa hasil usaha memiliki hubungan yang lemah. Artinya semakin efektif penggunaan modal kerja berpengaruh kecil terhadap perolehan SHU. Koefisien determinasi bernilai 6,45\% berarti tingkat perolehan sisa hasil usaha dipengaruhi oleh tingkat perputaran modal kerja sebesar $6,45 \%$ dan sisanya $93,55 \%$ dipengaruhi faktor lain.

\section{SARAN}

Berdasarkan hasil pembahasan tersebutmaka penulis memberikan saran yang diharapkan dapat membantu koperasi dalam aktivitas usahanya diantaranya yaitu:

1. Untuk meningkatkan perputaran kas maka yang perlu dilakukan oleh pengurus koperasi adalah meningkatkan volume penjualan, yaitu dengan cara memperluas usaha dan memperbanyak jenis barang yang dibutuhkan anggota tentunya dengan harga sesuai pasaran atau bahkan lebih murah.

2. Untuk meningkatkan perputaran piutang yang harus dilakukan adalah dengan menetapkan syarat yang jelas. 


\section{REFERENSI}

[1] Abdullah. Shahab. 1989. Accounting Principles, Edisi 9. Bandung : SAS.

[2] Alfred Hannel (1989), Pokok-Pokok Mengenai Organisasi Koperasi dan Kebijaksanaan Perkembangan di Negara-Negara Berkembang, Universitas Padjajaran, Bandung.

[3] Bambang Riyanto (2001), Dasar-dasar Pembelanjaan Perusahaan. BPFE, Yogyakarta.

[4] Hendar dan Kusnadi. 2002. Ekonomi Koperasi. Jakarta: Lembaga Penerbit Fakultas Ekonomi Universitas Indonesia.

[5] Mulyadi (1993), Akuntansi Biaya, Sekolah Tinggi Ilmu Ekonomi YKPN.

[6] Republik Indonesia, Undang-Undang No. 25 Tahun 1992, Tentang Perkoperasian.

[7] Rusidi (1993), Pedoman Penelitian dan Penulisan Karya Ilmiah, Penerbit UPT IKOPIN (Institut Manajemen Koperasi Indonesia), Bandung.

[8] Sugiyono (2002), Statistika Untuk Penelitian. Alfabeta, Bandung.

[9] Zaki, Baridwan (1992), Intermediate Accounting, Universitas Gadja Mada, Yogyakarta. 